\title{
Diaspora Remittances and Financial Inclusion in Kenya
}

\author{
Emmanuel Kwesi Arthur, Salome Mwongeli Musau, and Festus Mithi Wanjohi
}

\begin{abstract}
This study examined the effect of diaspora remittances on financial inclusion in Kenya for a quarterly period from 2008 to 2018 . The Kenyan government's commitment to include the Kenyan diaspora into the national development process led to the launching of Kenyan Diaspora Policy in 2015 as part of the Kenya's vision 2030 blue print of which financial inclusion is a pillar. This study sought to check if the policy interventions achieved its objective by testing the moderating effect of Diaspora Policy on the relationship between diaspora remittances and financial inclusion. The descriptive research design specifically longitudinal and explanatory non-experimental designs were employed in this study. The target population for this study comprised the three million Kenyans living at the diaspora. The census and stratified sampling design were utilised where census method was first used to include the formal diaspora remittance inflows for the forty four quarterly period and then stratified into corridors for the period under study. Data from the Central Bank of Kenya and Kenya National Bureau of Statistics were analysed using time series multiple regression model. The results of the study showed that formal diaspora remittances received had a positive and statistically significant effect on financial inclusion. Formal diaspora remittances from Rest of the World greatly influenced financial inclusion. Remittance inflows from North America also influenced financial inclusion to some extent while formal diaspora remittances from Europe had no effect on financial inclusion in Kenya. Further, the study established that the moderating effect between formal diaspora remittances and financial inclusion was positive and statistically significant implying that the diaspora policy implemented by government greatly influenced diaspora remittances and financial inclusion in the right direction in Kenya. The study recommended among others, that government of Kenya continues to strategically strengthen the diaspora policies in order to increase the flow of diaspora remittances into the country to boost financial inclusion.
\end{abstract}

Index Terms - Diaspora Remittances, Financial Inclusion, Diaspora Policy, Corridors, Kenya.

\section{INTRODUCTION}

The continuous increase in globalization has significantly influenced migration of individuals and funds from one geographical area to another for varying reasons (Czaika \& Hein de Haas, 2014). According to World Bank's Migration and Development brief 2019, annual remittance streams to low and middle-income countries touched US\$ 529 billion in 2018 as against the previous record of US\$ 483 billion in 2017 , causing an increase of 9.6 percent. Global remittances including flows to high-income countries in 2018 reached US\$ 689 billion up from US\$ 633 billion in 2017 (World Bank, 2019). According to World Bank and KNOMAD (2019), diaspora remittances to Sub-Saharan Africa has had a significant increase of almost 10 percent to US \$ 46 billion in 2018. In Kenya, diaspora remittance for 2018 grew by 39 percent to US \$ 2.697 billion (K.sh 274.37 billion) from 2017's US \$ 1.947 billion (K.sh 198.07 billion) (CBK, 2019). These huge inflows and outflows have become a global concern over the years and researchers in both policy and academia are interested in finding the contribution of remittances to financial access and inclusion in both the countries where the migrants migrated from and countries where they settled (Ambrosius \& Cuecuecha, 2016).

Financial inclusion in Kenya has greatly improved with an overall inclusion of 82.9 percent in 2019 while the informal category declined from 32.1 in 2006 percent to 6.1 percent in 2019 and the excluded category, 41.3 percent in 2006 to 11 percent in 2019. These developments is largely attributed to the introduction of mobile financial services in 2007, followed by increased partnerships and innovations such as mobile banking, agency banking, digital finance and mobile apps. Mobile money has acted as an 'on-ramp' for formal financial inclusion especially via digital finance.

Several studies have shown that remittances improve financial inclusion in many parts of the world. According to Anzoategui, Demirgüc-Kunt, \& Peria, (2014), increase in diaspora remittances may increase financial inclusion by the increased demand for deposit services at formal financial institutions because households need these services for the safe storage of their temporary excess funds (Aggarwal, Demirgüc-Kunt, \& Peria, 2011). This increases households' creditworthiness and the likelihood of obtaining loans from formal financial institutions. However, diaspora remittances may also function as a replacement for credit by relaxing households' credit-constraints, hence, reducing the demand for loans by households' from formal financial institutions. Moreover, remittance flows through formal channels provide opportunities for encouraging savings, increasing deposits and improving financial inclusion and development (IFAD \& World Bank Group, 2015; Al-Tarawneh, 2016).

\section{A. Financial Inclusion}

Financial inclusion is simply the ease of availability, accessibility, and usage of the formal financial institutions by all members of the economy. According to Mbutor and Uba (2013), financial inclusion is the increase in the number of people in an economy who are banked and hence holding a formal bank account with banks and other formal financial institutions. Financial inclusion aims at improving the use of formal mode of payments, such as internet payments, mobile payments and others by populace.

According to Sarma (2008), Availability of banking services measures the extent to which banking service is readily accessible to people as and when it is needed. Availability of banking services can be measured as "the number of bank branches (per 1000 population) and/or the number of ATM per (1000 people)". Banking accessibility or penetration is measured as the "the size of 'banked' population thus, the proportion of the population having a bank account". An appropriate measure is by counting the

Published on April 27, 2020. 
number of accounts that are opened through financial institutions and approximating the proportion of the population to the accounts. Li, Salinas, Ramirez, Hoyo, and Serrano (2014) show that households that receive remittances are more likely to have access to savings account and to use a bank account than households that do not receive remittances.

Usage of banking services dimension represent the degree to which a person who holds an account with financial institution utilizes the banking services is one of the dimensions of financial inclusion. Sarma (2008) measures the usage dimension as a proportion of the volume of credit and deposit to GDP. Mbaye (2015) reveals that receipt of remittances increases the possibility of having a loan facility in a household, thus increasing the likelihood that these inflows influence volume of credit. Anzoategui, DemirgücKunt, \& Peria, (2014) finds that households that receive remittances are more likely to have access to a deposit account at a financial institution. These findings assert that inflows of diaspora remittances influence the volume of deposits.

In this study, the financial inclusion indicators were number of bank accounts, volume of deposits and credits to GDP. The financial inclusion indicators (number of bank accounts, volume of deposits to GDP and volume of credits to GDP) were combined to form composite financial inclusion to assess the overall effect of diaspora remittances on financial inclusion.

\section{B. Diaspora Remittances}

According to Githaiga (2014), diaspora remittances are amounts of money sent by individuals living or working outside their countries of birth or naturalization to their home countries for the purpose of family consumption, savings or investments by migrants or for other purposes.

According to Akumbo, Nyaaba, and Akologo (2018), diaspora remittances channels may either take the formal or the informal channel. The international standard sector on anti-money laundering (AML), combating the financing of terrorism (CFT) and FATF generally describe "Formal Channels" funds transfer as those included in the regulated financial system, leaving all other methods in the "Informal Channel" category. The informal channels, on the other hand, refers to all types of remittance transfer services that do not involve formal channels, and hence are not likely to be recorded in national accounts. This usually comprise $10 \%$ to $50 \%$ of the total diaspora remittances inflows (Freund \& Spatafora, 2008).

In this study, formal diaspora remittances received per corridor (North America, Europe and Rest of the World) were adopted. Remittances from the Rest of the World were mostly from African countries such as South Africa, Rwanda, Uganda, Tanzania, etc. Some internet money remitting channels like WorldRemit and Wave are able to facilitate the transfer of money directly from diaspora to an MPesa account in Kenya.

\section{Diaspora Policy}

The Kenyan government's policy towards the diaspora, which is guided by the Diaspora Policy, was launched in 2015 as part of Kenya Vision 2030 agenda. In this policy, government of Kenya expressed its commitment to devise measures and interventions to influence the potentials of Kenyans abroad to contribute to the country's transformation agenda, while meeting their needs and expectations through a mutually beneficial and lasting partnership. One of the policy's strategic objectives is to develop and implement strategies to engage, empower and include Kenyans abroad in the nation's development process by leveraging information and communication technology in order to reduce money transfer costs. This study employed diaspora policy as a dummy variable where the compliance and none compliance parameters were used to check if the implementation of the policy in 2015 influenced the relationship between diaspora remittances and financial inclusion or not.

\section{Diaspora Remittances in Kenya}

Misati and Kamau, (2018) assert that diaspora remittances in Kenya have steadily improved at an average annual rate of 14.3 percent in the last one decade (2007- 2016), rising from US \$ 934 million in 2011 to US \$ 1.73 billion in 2016, constituting an average of 2.5 percent of GDP. Kenya is one of the top eight highest remittance-receiving countries in Africa after Nigeria, Egypt, Morocco, Tunisia, Ghana, Algeria and Senegal. However, Kenya remains the highest receiving diaspora remittance in East Africa in 2018 followed by Uganda ( $\$ 6.28$ billion), South Sudan ( $\$ 2.85$ billion), Tanzania (\$ 2.39 billion), Rwanda (\$ 1.13 billion) and Burundi (\$ 257 million).

Diaspora remittances to Kenya have been consistently increasing, recording higher levels than foreign direct investment and portfolio equity flows yet the statistics only reflect diaspora remittance flows through formal channels, which is believed to be grossly underestimated since migrants send money through informal channels and in-kind transfers that is often unrecorded (CBK, 2015). The trend of remittance inflows to Kenya from 2009 to 2018 has been shown below

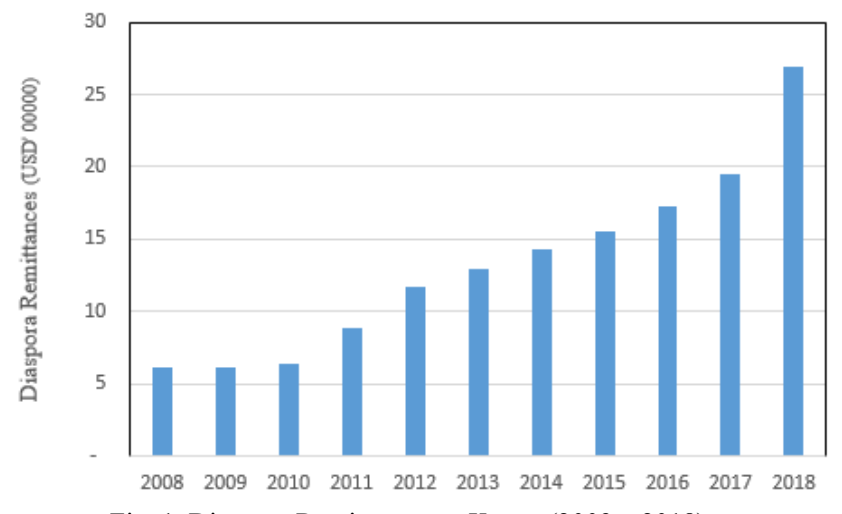

Fig. 1. Diaspora Remittances to Kenya (2009 - 2018) Source: Central Bank of Kenya (2018)

Given the increasing volume of remittances to Kenya, these inflows can be beneficial to many individuals and households: through effective distribution of useful funds, better access to finance, thus encouraging faster and impartial growth in sinking income disparity and poverty reduction. 


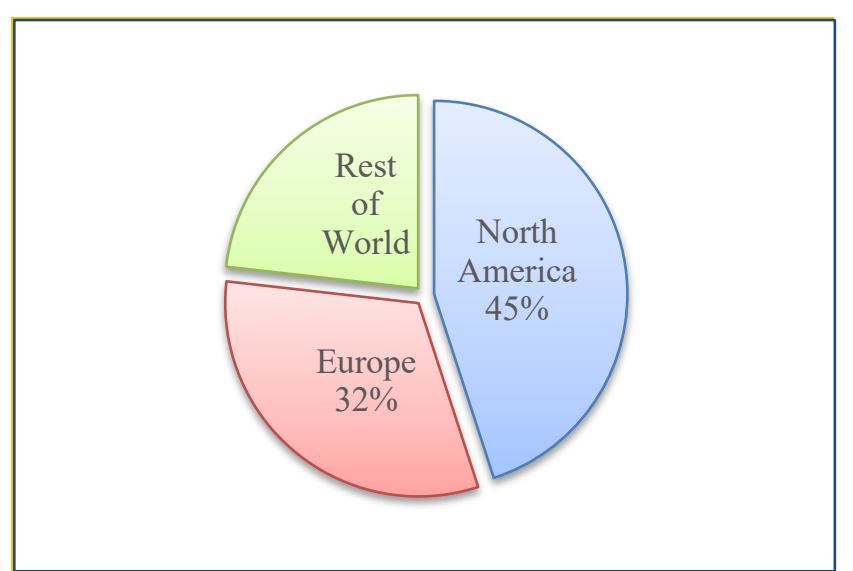

Fig. 1. Diaspora Remittances by corridors to Kenya. Source: Central Bank of Kenya (2018).

Kenya receives its highest remittance flows from North America followed by Europe and Rest of World. In December 2018 commentary of diaspora remittances, inflows from North America represented 45\% (US \$ 109.7 million) while that of Europe and Rest of world were 31.8 percent (US \$ 77.4 million) and 23.2 percent (US \$ 56.5 million) respectively. These numbers indicate where the focus should be laid in terms of bilateral agreements to ease and enhance diaspora remittance flows as well as where commercial banks, mobile companies, and online remittance platforms, would concentrate to attract more remittance flows and enlarge their market territory. The Government can also focus on these concentration corridors in terms of incentives and conducive policies to harness the flows.

\section{STATEMENT OF THE PROBLEM}

The FinAccess, 2019 report on financial inclusion in Kenya revealed that there is a decline in the usage of bank accounts from 31.7 percent in 2016 to 29.6 percent in 2019. This could place a huge impact on the volumes of deposits and credits if the usage of bank accounts continue to decline. Furthermore, the $5^{\text {th }}$ Annual lecture by Dr. David Ferrand, former CEO of FSD Kenya revealed that the increased financial inclusion of 82.9 percent does not reflect in the financial health of the economy eliciting that some indicators are not working well. With regards to policy, the Kenyan government's commitment to include the Kenyan diaspora into the national development process led to the launching of Kenyan Diaspora Policy in 2015 as part of Kenya's vision 2030 blueprint of which financial inclusion is a pillar. This study sought to check if the policy interventions by the government of Kenya achieved its objective.

According to Misati and Kamau (2018), diaspora remittances were traditionally considered as an income to supplement consumption; as a result, not many countries in Africa, including Kenya, have structures to channel it towards improvement in the financial sector and the economy a whole. According Filippo, Lensink, Van den Berg and Juárez (2014), such volumes of inflows can be leveraged to improve the sector by creating accessible, tailor-made products and services to reach millions of people in the rural areas. Given the importance of diaspora remittances on financial inclusion, this study aimed at enriching the existing literature by studying the effect of diaspora remittances on financial inclusion in Kenya, guided by the following specific objectives and hypothesis respectively:

i. To determine the effect of formal diaspora remittances received per corridor on financial inclusion in Kenya.

ii. To assess the effect of formal diaspora remittances on financial inclusion in Kenya.

iii. To establish the moderating effect of diaspora policy on the relationship between formal diaspora remittances and financial inclusion in Kenya.

The following null hypotheses guided this study:

$\mathrm{H}_{01}$ : Formal diaspora remittances received per corridor have no effect on financial inclusion in Kenya.

$\mathrm{H}_{02}$ : Formal diaspora remittances have no effect on financial inclusion in Kenya.

H03: Diaspora policy has no moderating effect on the relationship between formal diaspora remittances and financial inclusion in Kenya.

\section{LITERATURE REVIEW}

\section{A. Theoretical Review}

This study is anchored on the theory of Information asymmetry and pure altruism theory.

\section{Information Asymmetry}

The theory of asymmetric information finds its roots in the writings of George Akerlof's 1970 study titled, The Market for 'Lemons': Quality Uncertainty and the Market Mechanism, Michael Spence's Job Market Signaling in 1973 and Joseph Stiglitz's theory of market screening and several significant papers highlighting asymmetry in insurance markets. This theory was developed as a plausible explanation to the imbalance of information between market participants leading to inefficient outcomes in certain markets.

Considerable arguments contend that a regular flow of diaspora remittances facilitates creation of a credit history that establishes credit worthiness of the recipients and possibility of considering the current and potential remittance flows as collateral for credit allocation which intends reduces information asymmetric problems (Misati \& Kamau, 2018; Toxopeus \& Lensink, 2008). This is supported by Anzoategui, Demirgüc-Kunt, \& Peria, (2014), who argues that diaspora remittances might increase household likelihood of obtaining financial products and services such as loans (credits) since processing diaspora remittance flows provide financial institutions with information on income of recipient households. This information might make financial institutions willing and able to give credits and other financial products to remittance receivers (Brown, Carmignani, \& Fayad, 2013).

\section{Pure Altruism, Pure Self-Interest and Tampered \\ Altruism}

Lucas and Stark in their study, Motivations to Remit: Evidence from Botswana (1985) hypothesized theories of remittances into three groups, thus, Pure Altruism, Pure Selfinterest and Tempered Altruism. These theories explain the basic reasons why migrants remit money to their home countries.

With pure altruism theory, the satisfaction of the migrant depends not only on his/her own consumption but also on the satisfaction of the relatives in the home country (Lukas \& Stark, 1985. Altruistic feelings of the migrant may be a motivation for transfer remittances to family and relatives left 
behind. The migrant thus cares about poverty and other family shocks and consequently sends remittances. In this case, a family plays the role of an insurance company by providing members with protection against income shocks by diversifying the resources of income (Stark, 1991). Much of the literature on causes of diaspora remittances has been based on altruism as the main cause of decision to send money back home. Aggarwal and Horowitz (2002) conducted a study in Guyana and the evidence suggests that migrants are motivated by altruistic reasons to send remittances back home.

For pure self-interest, the theory generates three motives for remitting money back to the home country. According to Wendell (2014), the first motive emanates from the belief that if the migrant takes care of the family, a greater portion of the family's resources will be bequeathed to her. This motive predicts that the higher the remittances, the higher the potential inheritance. The second motive is to build up assets at home such as land, houses and livestock, which would require that family member act as an agent to acquire the assets and maintain them in good condition. The last motive may arise from an intent to return home at a later stage which would require investment in non-currrent assets, in a business or in community projects if the migrant has political ambitions. The remittances sent by the migrant are used to care for the migrant's interests, but they also contain some compensation for the agents (Chami, Fullenkamp and Jahjah, 2003)

According to Lucas and Stack (1985), pure altruism or pure self - interest alone cannot provide adequate explanations of the extent of diaspora remittances and its variability through time and across persons. They suggest a tempered altruism theory whereby diaspora remittances are viewed as a part of inter-temporal, mutually beneficial contractual arrangements between the migrant and the family at home country. The contractual arrangements could be co-insurance, loan repayment and exchange of services.

\section{B. Empirical Review}

This empirical review aims at providing an understanding of the effect of remittances on financial inclusion.

Akumbo, Nyaaba, and Akologo (2018) investigated the extent to which remittances have impacted financial inclusion in Ghana. A sample of 16772 enumerated households from the GLSS6 was used for the study. The study used Forced Entry Method to test the predictive ability of variables in the model. The study revealed that external remittances (remittances to and from abroad) only influenced the probability of opening a bank account, it does not have any significant impact on loan application and loan grant to households that engage in remittances. The study concluded that remittances, to a large extent improve financial inclusion in Ghana.

Aga and Martinez Peria (2014) with data from about 10,000 households in selected Sub-Sahara Africa countries postulated that international remittances from migrants to the countries under consideration have the tendency of increasing the use of formal account in the home countries. Similarly, Li, Salinas, Ramirez, Hoyo, and Serrano (2014), using primary data, show that people in households that receive diaspora remittances are more likely to be financially inclusive than those that do not receive diaspora remittances.
Demirgüc-Kunt, Córdova, Peria, \& Woodruff (2011), using the municipal-level data from Mexico, find that one percent increase in the share of households that receive diaspora remittances causes an increase in the percentage of households that use financial services by $0.16-0.19$ percentage points. Thus, their results show that there is a statistically significant relationship between diaspora remittances and financial inclusion. However, a study in Nigeria by Uchenna, Osabuohien and Oluwatobi (2015) contradicts this findings. Using the 2011 World Bank household survey, their study reveals that diaspora remittances do not influence the recipients' intention to open a bank account, hence diaspora remittances does not influence financial inclusion. They argue that this is due to the exchange rate in Nigeria: the recipients usually prefer to hold foreign currency due to unfavorable exchange rate.

In another study, Brown, Carmignani, and Fayad (2013) discussed the nonlinear behavior of bank credit in relation to financial inclusion and diaspora remittances by developing a theoretical model of bank credit in a hypothetical diaspora remittances receiving countries which used panel data set for a large group of developing and emerging economies within a 39 year time period $1970-2009$. The nonlinear relationship between bank credit and diaspora remittances implies that the curve associated with bank credit is U-shaped. This means that initially when diaspora remittance level is low, any increase reduces the volume of credit given bsy banks and but when the level of diaspora remittances is high, any increase increases the volume of credit given by banks with turning point at $2.5 \%$ of GDP. Also, deposits of diaspora remittance receipts in banks and other financial institutions increase funds readily available for loans thus banks' ability to extend credit to both remittance and non-remittance receiving households (Misati \& Kamau, 2018).

Ambrosius (2015) used data from the Mexican Family Life Survey (MxFLS) to examine the association between remittances and access to and usage of financial services. The MxFLS was an individual and household level panel data set that was representative of the national population. The paper found evidence that remittance were strongly associated with the opening of savings accounts and to some extent, make credit facilities available and concluded that remittances were a catalyst for poor households in rural areas to access financial services, but had less effect on wealthier households in urban areas. Further, remittances were more important to microfinance institutions rather than commercial banks.

Misati and Kamau (2018) analysed the effect of remittances on financial development (with financial inclusion indicators) using the autoregressive distributed lag (ARDL) method based on Kenyan quarterly data from 2006 to 2016. The study shows that usage of international remittance transfer through mobile technology reduces costs by eliminating the need for physical branches and personnel to attend to walk-in customers that dominates traditional remittance business models besides offering remittance actors convenience and safety. The study used financial inclusion indicators such as value of mobile transactions, number of mobile agents and number of bank accounts.

The results further showed a strong positive relationship implying that higher levels of remittances provide opportunities for opening bank accounts, enhancing savings 
and accessing financial systems for recipients besides exposing the unbanked to existing and new financial products. Ocharo (2014) investigated the effect of remittances on economic growth in Kenya. The ordinary least squares estimation method was used to determine the effect remittances had on economic growth. The study found that remittances as a ratio of GDP was positive and statistically significant. A shock in remittances as a ratio of GDP had an impact on economic growth in the first five periods, accounting for at most 4 percent of the variations in economic growth, and thereafter the impact fizzled out.

For Diaspora Policy on Diaspora Remittances and Financial Inclusion, Buencamino and Gorbunov (2002) observed that over the years governments were introducing a number of incentive based and mandatory measures to encourage migrants to remit more through formal channels. Commenting on the mandatory minimum remittance requirements introduced in Bangladesh, Republic of Korea, Pakistan and the Philippines they observed that mandatory measures were only successful where the government played an active role in the process by directly assisting local companies win contracts abroad. In turn, the local company deposited all or portion of the employees' earnings abroad in local banks.

El Qorchi, Maimbo and Wilson (2003), in their study, informal remittance systems, argued that developing international regulatory and supervisory standards for informal funds transfer systems is a complex process, and hence, called on regulators to note the differences in the stages of national economic development in general, and the financial sector in particular.

\section{METHODOLOGY}

Cooper and Schindler, 2008 explains that a research design is the overall blueprint that guides the researcher's work and helps in making informed decisions concerning the research methodology appropriate for the study. Descriptive research design specifically longitudinal and explanatory nonexperimental designs were employed in interrogating the influence of diaspora remittances on financial inclusion in Kenya.

Descriptive research design gives the researcher the chance to capture a population's characteristic and test hypothesis without manipulation or bias since the researcher has no control over the variables (Saunders, Lewis and Thornhill, 2019) while the explanatory non-experimental research design attempts to understand how diverse phenomena behaves, by establishing the contributing variables that usher in the change in it without applying any further analysis on the variable.

The target population for this study comprised over 3 million Kenyans living at the diaspora of which the census method was first used to include the total diaspora remittance inflows from 2008 to 2018. The stratified sampling method was then used to group them into corridors for the period under study. Formal diaspora remittance received was stratified per corridor for the respective quarters. The data were obtained from economic reviews and reports by Kenya National Bureau of Statistics, Central Bank of Kenya for the period of 2008 to 2018.

Descriptive statistics was used to summarize and profile the status of diaspora remittances, financial inclusion, and Diaspora Policy. Time series multiple regression analysis was carried out to test the nature of the relationship between diaspora remittances and financial inclusion in Kenya. The Pearson correlation matrix was used to determine the strength of the relationship between diaspora remittances and financial inclusion variables. Then, based on the outcome of the unit root test, the ARDL bound test was performed to establish whether a long run co integration relationship existed between diaspora remittances and financial inclusion.

\section{Empirical Model}

To analyse the effect of diaspora remittances on financial inclusion, time series multiple regression model was employed. In this study, simple regression model adapted from Mostak and Sushanta (2015) was expanded as indicated below:

$\operatorname{InNoBA} A_{t}=\alpha_{0}+\beta_{1} \ln N F D R_{t}+\beta_{2} \ln E F D R_{t}+\beta_{3} \ln R F D R_{t}+\varepsilon_{t} . .3 .1$ DGDP $_{\mathrm{t}}=\alpha_{0}+\beta_{1} \ln N F D R_{\mathrm{t}}+\beta_{2} \ln E F D R_{\mathrm{t}}+\beta_{3} \ln \operatorname{RFDR}_{\mathrm{t}}+\varepsilon_{t} \ldots . .3 .2$ CGDP $_{\mathrm{t}}=\alpha_{0}+\beta_{1} \ln N F D R_{\mathrm{t}}+\beta_{2} \ln$ EFDR $_{\mathrm{t}}+\beta_{3} \operatorname{lnRFDR} \mathrm{R}_{\mathrm{t}}+\varepsilon_{t} \ldots .3 .3$ $\mathrm{FI}_{\mathrm{t}}=\alpha_{0}+\beta_{1} \ln N F D R_{\mathrm{t}}+\beta_{2} \operatorname{lnEFDR} \mathrm{R}_{\mathrm{t}}+\beta_{3} \ln \operatorname{RFDR}_{\mathrm{t}}+\varepsilon_{t} \ldots \ldots \ldots .3 .4$

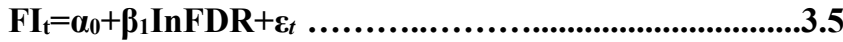

Where; InNoBAt represents natural log of number of bank accounts at time $t$

DGDP $_{t}$ represents volume of deposits to GDP at time $t$

CGDP represents volume of credits to GDP at time $t$

FI represents financial inclusion (composite) at time $t$

InNFDR $_{\mathbf{t}}$ represents natural $\log$ of formal diaspora remittances received from North America at time $t$

InEFDR $_{\mathbf{t}}$ represents natural $\log$ of formal diaspora remittances received from Europe at time $t$

InRFDR $_{\mathbf{t}}$ represents natural log of formal diaspora remittances received from Rest of the World at time $t$

InFDRt $_{\mathbf{t}}$ represents natural $\log$ of total formal diaspora remittance received at time $\mathrm{t}$

All the series in this study were transformed into natural log-form except volume of deposits and credits to GDP in order to reduce sharpness in the data to give more reliable results. Furthermore, log-linear specification performs better compared to the simple linear model and makes results more favorable (Shahbaz, Rehman, \& Afza, 2015).

To test for moderation, the researcher adopted Baron and Kenny (1986) to examine the moderating effect of Diaspora Policy on the relationship between diaspora remittances and financial inclusion in Kenya. This is presented by the equation below.

$\mathrm{FI}_{\mathrm{t}}=\alpha_{0}+\beta_{1} \ln F D R_{\mathrm{t}}+\beta_{2} \mathrm{DP}+\boldsymbol{\beta}_{3}\left(\ln F D R_{\mathrm{t}}\right)(\mathrm{DP})+\varepsilon_{t} \ldots \ldots \ldots \ldots . . .6$

Where DP is the moderating variable, Diaspora Policy

\section{FINDINGS AND DISCUSSION}

\section{A. Descriptive Statistics}

An exploratory data analysis conducted involves the descriptive statistics of mean, standard deviation, minimum as well as maximum values recorded in the study period. 
TABLE I: DESCRIPTIVE STATISTICS

\begin{tabular}{llllll}
\hline \hline Variables & Qbs & Mean & Std. Dev. & Max & Min \\
\hline NoBA & 40 & $25,103,299$ & $15,963,609$ & $55,527,752$ & $6,043,604$ \\
VoD/GDP & 42 & 3.250 & 0.507 & 4.013 & 2.426 \\
VoC/GDP & 42 & 2.467 & 0.518 & 3.204 & 1.627 \\
FDR & 44 & $31,016,257,541$ & $17,625,299,398$ & $75,448,951,353$ & $10,645,244,220$ \\
NFDR & 44 & $15,403,852$ & $9,176,634$ & $37,559,232$ & $4,539,213$ \\
EFDR & 44 & $8,983,384$ & $5,754,235$ & $24,779,741$ & $2,464,231$ \\
RFDR & 44 & $6,282,649$ & $3,205,700$ & $14,250,478$ & $1,296,004$ \\
\hline
\end{tabular}

Source: Study data $(2008$ - 2018)

From the findings in Table I, financial inclusion was measured by number of bank accounts, volume of deposits to GDP and volume of credits to GDP. The mean value of number of bank accounts for the period under the study was K.sh 25.10 million. The standard deviation of K.sh 15.96 million indicated a great variation in number of bank accounts for the period as evidenced by a maximum value of K.sh 55.53 million and minimum value of K.sh 6.04 million. The volume of deposits to GDP had an average of 3.250 points with a standard deviation of 0.507 points and the highest points were 4.013 and lowest points 2.426 for the period 2008 - 2018. The mean value of volume of credits to GDP was 2.47 points with a standard deviation of 0.5518 points and a minimum and maximum values of 1.627 points and 3.204 points respectively which was an indication of high variation in volume of credits to GDP from the mean.

Diaspora Remittances was measured by formal diaspora remittances which was stratified into corridors, thus, North America, Europe and Rest of the World. Formal diaspora remittances had an average value of K.sh 31.02 billion and a maximum value of K.sh 75.45 billion and minimum value of K.sh 10.65 billion. A standard deviation of K.sh 17.63 billion was an indication of a big dispersion of money supply from the mean. Formal diaspora remittances received from North America, Europe and Rest of the World had mean values of K.sh 15.40 million, 8.98 million and 6.28 million respectively with a maximum values of K.sh 37.56 million, K.sh 24.78 million and K.sh 14.25 million and minimum values of K.sh 4.54 million, K.sh 2.46 million and K.sh 1.30 million. A standard deviation of K.sh 9.18 million was an indication of a high variation of formal diaspora remittances received from North America compared to standard deviations of formal diaspora remittances received from Europe, K.sh 5.75 million and the Rest of the World, K.sh 3.21 million from their means which indicated low variation from the mean.

These results show that financial inclusion has been experiencing steady growth since the variation was not as wide as that of diaspora remittances. Formal diaspora remittances received from the three corridors (North America, Europe and Rest of the World) experienced wide variations. This indicates that a change in government interventions towards diaspora remittances and financial inclusion could cause a greater change in formal diaspora remittance inflows than in financial inclusion.

\section{B. Inferential Statistics - Hypothesis Testing}

In order to establish the relationship between diaspora remittance and financial inclusion, the study conducted robust regression analysis for each of the indictors of financial inclusion. This was based on the fact that the error terms were not constant hence the need to control for heteroscedasticity as recommended by Welsh (1996). Hypotheses $\mathrm{H}_{01}, \mathrm{H}_{02}$ and $\mathrm{H}_{03}$ were based on diaspora remittances indicators and were analyzed using time series multiple regression to establish the statistical significance at 95 percent confidence level $(\alpha=0.05)$.

The adjusted $\mathrm{R}^{2}$ squared for all the results accounted for high explanatory power among the parameters of diaspora remittances and financial inclusion. The study showed that Pvalue of F-statistics at 5\% level of significance for all the results were 0.000 which confirmed the model significance. The model significance results confirmed the suitability of diaspora remittance in predicting variations in financial inclusion in Kenya. The results show that the models had a goodness of fit

\section{Formal Diaspora Remittances on Number of Bank Accounts in Kenya}

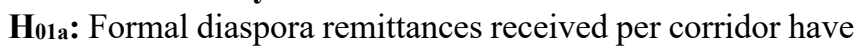
no effect on number of bank accounts in Kenya.

TABLE II: EFFECT OF FORMER DIASPORA REMITTANCES PER CORRIDOR ON NUMBER OF BANK ACCOUNTS

\begin{tabular}{llrrrrr}
\hline \hline NOBA & Coef. & Std. Err. & $\mathbf{t}$ & $\mathbf{P}>|\mathbf{t}|$ & [95\% Conf. & Interval] \\
\hline NFDR & 0.990272 & 0.28483 & 3.48 & 0.001 & 0.412609 & 1.567935 \\
EFDR & 0.387749 & 0.271914 & 1.43 & 0.162 & -0.16372 & 0.939215 \\
RFDR & 0.085739 & 0.156882 & 0.55 & 0.588 & -0.23243 & 0.403911 \\
_cons & -0.15296 & 0.865667 & -0.18 & 0.861 & -1.90862 & 1.60269 \\
\hline F $(\mathbf{3}, \mathbf{3 6})=\mathbf{1 6 3 . 4 3}$ & & & & & & \\
Prob $>\mathbf{F}=\mathbf{0 . 0 0 0 0}$ & & & & & & \\
R-squared $=\mathbf{0 . 9 3 1 6}$ & & & & & & \\
Adj R-squared $=\mathbf{0 . 9 2 5 9}$ & & & & & & \\
\hline \hline
\end{tabular}

Source: Study data (2008-2018)

The estimation of the model is reported in Table II as:

NoBA $=-0.153+0.990 N F D R+0.388 E F D R+0.086 R F D R . .3 .1$

The results show that formal diaspora remittances from North America $(\beta=0.990, p=\mathbf{0 . 0 0 1}<\mathbf{0 . 0 5})$ positively and significantly affected financial inclusion as measured by number of bank accounts. However, formal diaspora remittances received from Europe $(\beta=0.388, \mathrm{p}=\mathbf{0 . 1 6 2}>\mathbf{0 . 0 5})$ and from the Rest of the World $(\beta=0.086, p=\mathbf{0 . 5 8 8}>\mathbf{0 . 0 5})$ have positive but no significant effect on the number of bank accounts in Kenya.

The positive coefficient of 0.990 for North America in the findings indicates that an increase in formal diaspora remittances from North America increases number of banks accounts by 99.0 percent, hence improving financial inclusion. The findings confirmed that some remittances corridors are significant compared to others in terms on influencing financial inclusion in Kenya.

The results are consistent with Akumbo, Nyaaba, and Akologo (2018) who investigated the extent to which remittances impacted financial inclusion in Ghana. The findings revealed that external remittance (to and from abroad) only influenced the probability of opening bank account, hence improving financial inclusion in Ghana. This result is also consistent with Misati and Kamau (2018) whose results show a strong positive relationship implying that 
higher levels of remittances provide opportunities for opening bank accounts and enhancing access to savings and financial systems.

However, the results of formal diaspora remittances from Europe and the Rest of the World were also consistent with a study by Uchenna, Osabuohien and Oluwatobi (2015) whose study revealed that diaspora remittances do not influence the recipients' intention to open a bank account, hence, not influencing financial inclusion. They argue that this is due to the exchange rate in Nigeria: the recipients usually prefer to hold foreign currency due to unfavorable exchange rate.

\section{Formal Diaspora Remittances on Volume of Deposits to} GDP in Kenya.

Ho1b: Formal diaspora remittances received per corridor have no effect on volume of deposits to GDP in Kenya.

TABLE III: EFFECT OF DIASPORA REMITTANCES ON VOLUME OF DEPOSITS PER CORRIDOR TO GDP

\begin{tabular}{lllllrl}
\hline \hline VODGDP & Coef. & Std. Err. & T & $\mathbf{p}>|\mathbf{t}|$ & [95\% Conf. & Interval] \\
\hline NFDR & 0.479743 & 0.233626 & 2.05 & 0.047 & 0.006793 & 0.952694 \\
EFDR & 0.214772 & 0.224838 & 0.96 & 0.345 & -0.24039 & 0.669933 \\
RFDR & 0.291718 & 0.120007 & 2.43 & 0.020 & 0.048777 & 0.534659 \\
_cons & -8.05618 & 0.663981 & -12.13 & 0.000 & -9.40034 & -6.71202 \\
\hline
\end{tabular}

$\mathrm{F}(3,38)=128.65$

Prob $>\mathrm{F}=0.0000$

R-squared $=0.9104$

Adj R-squared $=0.9033$

Source: Study data (2008-2018)

The estimation of the model is reported in Table III as: VoD/GDP=-8.06+0.48NFDR+0.22EFDR+0.29RFDR...3.2

The results show that formal diaspora remittances from North America $(\beta=0.480, p=\mathbf{0 . 0 4 7}<\mathbf{0 . 0 5})$ and Rest of the World $(\beta=0.292, p=\mathbf{0 . 0 2 0}<\mathbf{0 . 0 5})$ have positive and statistical significant effect on financial inclusion as measured by volume of deposits. However, formal diaspora remittances received from Europe $(\beta=0.215, p=\mathbf{0 . 3 4 5}>\mathbf{0 . 0 5})$ has no significant effect on the volume of deposits in Kenya.

While the formal diaspora remittances from North America and Rest of the World have positive statistical significant effect on volume of deposits to GDP, the formal diaspora remittances from Europe have no significant effect on volume of deposits to GDP. The positive coefficient of 0.480 and 0.292 indicate that an increase in formal diaspora remittances from North America increases volume of deposits to GDP by 48 percent while formal diaspora remittances from Rest of the World increases the volume of deposits to GDP by 29.2 percent, hence improving financial inclusion.

The findings confirmed that formal diaspora remittance from North America and Rest of the World is statistically significant, hence improving financial inclusion while that of Europe did not influence financial inclusion in Kenya. The results from the North America and Rest of the World collaborate with Anzoategui, Demirgüc-Kunt, \& Peria, (2014) findings which established that households that receive remittances are more likely to influence financial inclusion by having a deposit account which increases the volume of deposits at a financial institutions.

However, results from Europe was inconsistent with the results of Shrestha and Joshi (2018) which established that remittances have negative impact on financial inclusion by decreasing the likelihood of having a deposit account which has the capacity of increasing the volume of deposits.

Formal Diaspora Remittances on Volume of Credits to GDP in Kenya

H01c: Formal diaspora remittances received per corridor have no effect on volume of credits to GDP in Kenya.

TABLE IV: EFFECT OF DIASPORA REMITTANCES ON VOLUME OF CREDITS TO GDP

\begin{tabular}{lllrrrr}
\hline \hline VOC/GDP & Coef. & Std. Err. & \multicolumn{1}{c}{$\mathbf{t}$} & $\mathbf{p}>|\mathbf{t}|$ & {$[\mathbf{9 5} \%$ Conf. } & Interval $]$ \\
\hline NFDR & -0.03683 & 0.275604 & -0.13 & 0.894 & -0.59476 & 0.521106 \\
EFDR & 0.237694 & 0.265237 & 0.9 & 0.376 & -0.29925 & 0.774639 \\
RFDR & 0.744464 & 0.14157 & 5.26 & 0.000 & 0.457871 & 1.031057 \\
_cons & -7.94478 & 0.783286 & -10.14 & 0.000 & -9.53046 & -6.3591 \\
\hline
\end{tabular}

$\mathrm{F}(3,38)=93.07$

Prob $>\mathrm{F}=0.0000$

R-squared $=0.8802$

Adj R-squared $=0.8707$

Source: Study data (2008-2018)

The estimation of the model is reported in Table IV as: VoC/GDP=-7.95-0.04NFDR+0.24EFDR+0.74RFDR...3.4

The results show that formal diaspora remittances from North America $(\beta=-0.037, p=\mathbf{0 . 8 9 4}>\mathbf{0 . 0 5})$ have negative but statistically insignificant effect on financial inclusion while that of Europe $(\beta=0.238, p=\mathbf{0 . 3 7 6}>\mathbf{0 . 0 5})$ have positive but statistically insignificantly effect on financial inclusion as measured by volume of credits to GDP. However, formal diaspora remittances received from Rest of the World $(\beta=0.744, p=\mathbf{0 . 0 0 0}>\mathbf{0 . 0 5})$ have no effect on the volume of credits to GDP.

Formal diaspora remittances from the Rest of the World has a positive statistical significant effect on volume of credits to GDP. This shows that only formal diaspora remittances received from Rest of the World influences financial inclusion through volume of credits to GDP. The positive coefficient of 0.744 indicates that an increase in formal diaspora remittances from Rest of the World increases the volume of credits to GDP by 74.4 percent, hence improving financial inclusion.

The results is inconsistent with the findings of Shrestha and Joshi (2018) which established that remittances have negative impact on financial inclusion by decreasing the likelihood of having a credit/loan account which has the capacity of increasing the volume of credits. However, the results from the Rest of the Word collaborate with Ambrosius and Cuecuecha (2016) findings which established that there are positive effects of remittances on existence of debts and borrowing which influences volume of credits at a financial institutions.

Diaspora Remittances per corridor and Financial Inclusion in Kenya

H01d: Diaspora remittances have no effect on financial inclusion in Kenya.

In this model, the study sought to test the effect of diaspora remittances on financial inclusion which was a composite variable of (Number of Bank Account, VoD/GDP and VoC/GDP). The results are presented in Table $\mathrm{V}$ shown 
below.

TABLE V: EFFECT OF DIASPORA REMITTANCES ON FINANCIAL INCLUSION (COMPOSITE)

\begin{tabular}{lllllll}
\hline \hline FI & Coef, & Std. Err. & t & P> $|\mathbf{t}|$ & {$[\mathbf{9 5 \%}$ Conf. } & Interval] \\
\hline NFDR & 24.47552 & 28.62233 & 0.86 & 0.398 & -33.5733 & 82.52429 \\
EFDR & 47.40564 & 27.32432 & 1.73 & 0.091 & -8.01064 & 102.8219 \\
RFDR & 33.79868 & 15.76493 & 2.14 & 0.039 & 1.825923 & 65.77143 \\
_cons & -1052.38 & 86.99005 & -12.1 & 0.000 & -1228.81 & -875.959
\end{tabular}

$\mathrm{F}(3,36)=91.94$

Prob $>\mathrm{F}=0.0000$

R-squared $=0.8845$

Adj R-squared $=0.8749$

Source: Study data (2008-2018)

The estimation of the model is reported in Table $\mathrm{V}$ as: $\mathrm{FI}=-1052.38+24.48 \mathrm{NFDR}+47.41 \mathrm{EFDR}+33.80 \mathrm{RFDR}$...3.5

The results show that formal diaspora remittances from Rest of the World $(\beta=33.80, p=\mathbf{0 . 0 3 9}<\mathbf{0 . 0 5})$ had a positive statistical significant effect on financial inclusion. The positive coefficient of 33.80 in the findings indicate that an increase in formal diaspora remittances increases financial inclusion by 33.80 times, hence improving financial inclusion. Formal diaspora remittances from North America $(\beta=24.48, p=\mathbf{0 . 3 9 8}>\mathbf{0 . 0 5})$ and Europe $(\beta=47.41, p=\mathbf{0 . 0 9 1}<$ 0.05) had a positive but statistically insignificant effect on financial inclusion.

While the results of formal diaspora remittances received from Rest of the World is collaborate with a finding by Misati and Kamau (2018) whose study revealed that diaspora remittances show a strong positive relationship, implying that higher levels of remittances provide opportunities for opening bank accounts, enhancing savings (deposits) and accessing financial systems such as loans (credits), it is inconsistent with formal diaspora remittances from North America and Europe.

\section{Formal Diaspora Remittances and Financial inclusion in} Kenya

$\mathbf{H}_{\mathbf{0 2}}$ : Formal diaspora remittances have no effect on financial inclusion in Kenya.

In this model, the study sought to test the effect of diaspora remittances on financial inclusion which was a composite variable of (Number of Bank Account, VoD/GDP and VoC/GDP). The results are presented in Table VI shown below.

TABLE VI: EFFECT OF DIASPORA REMITTANCES ON FINANCIAL INCLUSION (COMPOSITE)

\begin{tabular}{llrrrrr}
\hline \hline FI & Coef. & Std. Err. & \multicolumn{1}{c}{$\mathbf{t}$} & $\mathbf{P}>|\mathbf{t}|$ & [95\% Conf. & Interval] \\
\hline FDR & 96.08847 & 4.710541 & 20.4 & 0.000 & 86.55248 & 105.6245 \\
_cons & 2158.08 & 112.604 & -19.17 & 0.000 & -2386.04 & -1930.13 \\
\hline
\end{tabular}

$\mathrm{F}(1,38)=416.10$

$\operatorname{Prob}>\mathrm{F}=0.0000$

R-squared $=0.9163$

Adj R-squared $=0.9141$

Source: Study data (2008-2018)
The estimation of the model is reported in Table VI as:

FI $=2158.08+96.09 F D R$

The results show that formal diaspora remittances $(\beta=96.09, p=\mathbf{0 . 0 0 0}<\mathbf{0 . 0 5})$ had a positive statistical significant effect on financial inclusion. The positive coefficient of 96.09 in the results indicate that an increase in formal diaspora remittances increases financial inclusion by 96.09 times, hence improving financial inclusion.

The results of formal diaspora remittances on financial inclusion is consistent with a study by Ambrosius and Cuecuecha (2016) whose findings reveal that there exists positive effects of remittances on the ownership of savings account (increasing number of bank accounts and improving deposits) and existence of debts and borrowings herein referred to as credit.

\section{Moderating Effect of Diaspora Policy}

Robust regression equations were obtained after moderation to determine the moderating effect of formal diaspora remittances on financial inclusion in Kenya. The moderating variable was measured using Diaspora Policy as a dummy variable to determine whether there was compliance or not.

Moderating Effect of Formal Diaspora Remittances on Financial Inclusion in Kenya

H03: Diaspora Policy has no significant moderating effect on the relationship between formal diaspora remittances and financial inclusion (composite) in Kenya.

TABLE VII: MODERATING EFFECT OF DIASPORA POLICY ON FORMAL DIASPORA REMITTANCES AND FINANCIAL INCLUSION (COMPOSITE).

\begin{tabular}{lcccccc}
\hline \hline FI & Coef. & Std. Err. & $\mathbf{t}$ & $\mathbf{P}>|\mathbf{t}|$ & {$[\mathbf{9 5 \%}$ Conf. } & Interval] \\
\hline FDR & 90.16796 & 4.549771 & 19.82 & 0.000 & 80.9406 & 99.39533 \\
$\mathbf{D P}$ & 3801.008 & 538.0283 & 7.06 & 0.000 & 2709.836 & 4892.18 \\
$\mathbf{F D R} * \mathbf{D P}$ & -154.60 & 21.99165 & -7.03 & 0.000 & -199.201 & -109.999 \\
Cons & -2020.54 & 107.5768 & -18.78 & 0.000 & -2238.72 & -1802.37 \\
\hline $\mathbf{F}(\mathbf{3}, \mathbf{3 6})=\mathbf{3 8 3 . 5 6}$ & & & & & & \\
Prob $>\mathbf{F}=\mathbf{0 . 0 0 0 0}$ & & & & & & \\
R-squared = 0.9697 & & & & & & \\
Adj R-squared $=\mathbf{0 . 9 6 7 1}$ & & & & & & \\
\hline \hline
\end{tabular}

Source: Study data (2008-2018)

$\mathrm{FI}_{\mathrm{t}}=\mathbf{- 2 0 2 1}+90 \mathrm{FDR}+3801 \mathrm{DP}-155(\operatorname{lnFDRt})(\mathrm{DP})$

The result in Table VII indicates an adjusted R-squared of 0.9671. This implies that when diaspora policy were introduced as a moderator, the model had high predictive power on the relationship between formal diaspora remittances and financial inclusion in Kenya as they accounted for 96.71 percent. This means that a combination formal diaspora remittances and diaspora policy as a moderator can adequately explain the variation in financial inclusion.

The coefficient of diaspora policy at $(\beta=3801, \mathrm{p}=$ $\mathbf{0 . 0 0 0}<\mathbf{0 . 0 5})$ shows a positive statistically significant relationship between diaspora policy and financial inclusion. This indicates that diaspora policy directly affect financial inclusion and thus can moderate the relationship between formal diaspora remittances and financial inclusion. The coefficient of 3801 obtained in this case implies that an increase in diaspora policy would lead to 3801 increases in financial inclusion. When formal diaspora remittances and 
diaspora policy are interacted (FDR*DP, $\beta=-154.60$, $\mathrm{p}=0.000<0.05)$, there is a negative but significant relationship. This imply that strict or increased policies adversely affects financial inclusion through formal diaspora remittances. The findings are consistent with Qorchi, Maimbo and Wilson (2003) who found that legal and regulatory framework surrounding diaspora remittances is very significant in influencing the amount of money remitted into a country. While they warned that too much restrictive regulations will negatively affect the amount of remittance inflows, the advocated for a relaxed regulations between countries to ensure huge inflows of remittances.

\section{SUMMARY AND CONCLUSION}

For the first objective, formal diaspora remittances received from North America was found to have positive statistical significant effect on financial inclusion measured by number of bank accounts while remittances inflow from Europe and Rest of the World had positive but insignificant effect on financial inclusion parameter, number of bank accounts. Formal diaspora remittances received from North America and Rest of the World was also found to have a positive statistical significant effect on financial inclusion proxied by volume of deposits to GDP while formal diaspora remittances received from Europe had positive but insignificant effect on volume of deposits to GDP.

While Rest of the World had positive and statistically significant effect on volume of credit to GDP, North America had negative but insignificant effect and Europe had a positive but insignificant effect on financial inclusion measured by volume of credits to GDP. Rest of the World as a formal diaspora remittance corridor, had a positive significant influence on financial inclusion (composite number of bank accounts, volume of deposits and credits to GDP) while formal diaspora remittances from North America and Europe had positive but statistically insignificant influence on financial inclusion.

On the second objective, formal diaspora remittances had a positive and significant effect on composite financial inclusion. Diaspora policy was found to moderate the relationship between formal diaspora remittances and financial inclusion represented by composite index of number of bank accounts, volume of deposits and credits to GDP.

The study therefore evidenced that as the size of formal diaspora remittances increase, it generates more opportunities for accessibility and usability of financial services within financial institutions. Although formal diaspora remittances from Rest of the World greatly influenced financial inclusion, inflows from North America also influenced financial inclusion to some extent while formal diaspora remittances from Europe had no effect on financial inclusion in Kenya.

\section{POLICY IMPLICATIONS AND RECOMMENDATIONS}

1. Formal diaspora remittances had positive and statistically significant effect on financial inclusion, implying that government of Kenya should work towards pursuing policies that attract the flow of formal diaspora remittances into the country to boost financial inclusion.

2. Policy interventions by government of Kenya and Central Bank of Kenya to introduce a number of incentive based measures to encourage migrants to remit more through formal channels should be observed and implemented by a committee set up by government and/or central bank of Kenya since the active role of these stakeholders in the process directly influence more remittance inflows.

3. The emergence of regulatory and policy framework approach to formal remittance systems need to satisfactorily take into account specific domestic circumstances especially the differences in the stages of national economic development in general, and the financial sector in particular.

\section{REFERENCES}

N. Aboulezz, "Remittances and economic growth nexus: empirical evidence from Kenya," International Journal of Academic Research in Business and Social Sciences, vol. 5, no. 12, pp. 285-296, 2015.

G. A. Aga, and M. S. Peria, "International remittances and financial inclusion in Sub-Saharan Africa." World Bank Policy Research Working Paper, no. 6991, 2014.

A. H. Welsh, "Robust estimation of smooth regression and spread functions and their derivatives," Statistica Sinica, pp. 347-366, 1996.

R Aggarwal, D. Asli, and M. Peria, "Do workers remittances promote financial development," Journal of Development Economics, vol. 96, no. 2, pp. 255-264, 2011.

R. Aggarwal, A. W. Horowitz, "Are International Remittances Altruism or Insurance?” Journal of Development Economics, vol. 30, no. 11, pp. 20332044, 2002.

G. A. Akerlof, "The market for "lemons": Quality uncertainty and the market mechanism," The Quarterly Journal of Economics. vol. 84, no.3, pp. $488-500,1970$.

S. E. M. Akumbo, R. A. Nyaaba, and D. A. Akologo, "Remittances and financial inclusion in Ghana," International Journal of Business, Economics and Law, vol. 16, no. 5, pp. 39-51, 2018.

A. Al-Tarawneh, "The role of workers' remittances in development of Jordanian banking sector," International Journal of Business and Economics Research, vol. 5, no. 6, pp. 227- 234, 2016.

C. Ambrosius, "Remittances and Financial Access: Is There Really a Link and for Whom? Evidence from Mexican Household Data," The World Economy, 2015

C. Ambrosius, and A. Cuecuecha, "Remittances and the use of formal and informal financial services," The World Development, vol. 77, no. C, pp. 8098, 2016.

D. Anzoategui, A. Demirguc-kunt, and S. Martinez, "Remittances and financial inclusion: Evidence from Elsavador," World Development," vol. 54, pp. 338-349, 2014.

M. Baron, and A. Kenny,'The Moderator-Mediator Variable Distinction in Social Psychological Research: Conceptual, Strategic and Statistical Considerations," Journal of Personality and Social Psychology, vol.51, no. 6, pp. 1173-1182, 1986.

R. Brown, F. Carmignani, and G. Fayad, "Migrants remittances and financial development: Macro and micro-level evidence of a perverse relationship," The World Economy, vol. 36, no. 5, pp. 636-660, 2013.

Buencamino and Gorbunov, "Informal Money Transfer Systems: opportunities and challenges for development finance," DESA Discussion Paper of the United Nations Department of Economics and Social Affairs, United Nations, no. 26, New York, 2002.

Central Bank of Kenya, "Commentary on Diaspora Remittances," Nairobi, Kenya, 2018.

Central Bank of Kenya, "Commentary on Diaspora Remittances," Nairobi, Kenya, 2019.

R. Chami, C. Fullenkamp, and S. Jahjah, "Are Immigrant Remittance Flows a Source of Capital for Development?" IMF Working paper, vol. 1, no. $189,2003$.

C. R. Cooper, and P. S. Schindler, Business Research Methods, 11th Ed., Boston: 2011, McGraw-Hill.

A. Demirguc-Kunt, E. L. Cordova, P. Martinez, M. S. and, C. Woodruff, "Remittances and Banking Sector Breadth and Depth. Evidence from Mexico," Journal of Development Economics, vol. 95, no. 2, pp. 229 - 241, 2011 .

A. Demirguç-Kunt, and R. Levine, "Stock markets, corporate finance, and Economic growth: An overview," World Bank Economic Review, vol. 10 no. 2, pp. 223-239, 2008.

M. El Qorchi, S. M. Maimbo and J. W. Wilson, "Informal Funds Transfer Systems: An Analysis of the Informal Hawala System," A Joint IMF-World Bank Paper. Occasional Paper No.222. International Monetary Fund, Washington, D.C., 2003. 
C. Filippo, R. Lensink, M. Van den Berg, and R. S. Juárez, "The impact of remittances on financial inclusion in Veracruz," Mexico, Wageningen University, 2014.

Financial Sector Deepening Kenya, Working towards the development of an inclusive financial ecosystem for all Kenyans: Fin Access National Survey, 2019.

C. L. Freund, and N. Spatafora,"Remittances: transaction costs, determinants, and informal flows," World Bank Policy Research Working Paper, no. $3704,2005$.

P. N. Githaiga, "Do Remittances Stimulate Private Sector Investment? A Case of Sub-Saharan Africa," European Journal of Business and Management, vol. 6, no. 29, 2014

IFAD \& World Bank Group, (2015). The use of remittances and financial inclusion. G20 Global Partnership for Financial Inclusion Report.

J. Li, J. Salinas, T. Ramirez, C. Hoyo, and, C. Serrano, "Do remittances foster financial inclusion in Mexico?" Financial Inclusion Economic Watch, BBVA Research, 2014.

R. E. B Lucas, and O. Stark, "Motivations to Remit: Evidence from Botswana," Journal of Political Economy, vol. 93, no. 5, pp. 901-918, 1985.

M. O. Mbutor, and I. A. Uba, "The impact of financial inclusion on monetary policy in Nigeria," Journal of Economics and International Finance, vol.5 no. 8, pp. 318, 2013.

R. Misati, and A. Kamau, "Do Migrant Remittances Matter for Financial Development In Kenya?" The Kenya Bankers Association (KBA) Working Papers, no. 30, WPS/08/18, 2018.

K. Ocharo, "Remittances and economic growth in Kenya," International Conference on Dynamics of Rural Transformation in Emerging Economics, pp. 27-28, 2014.

M. Saunders, P. Lewis, and A. Thornhill, Research methods for business students. Pearson Education ltd, London, 2019.

M. Shahbaz, I. Rehman, and T. Afza, "Macroeconomic Determinants of Stock Market Capitalization in an Emerging Market: Fresh Evidence from Co-integration with Unknown Structural Breaks," Macroeconomics and Finance in Emerging Market Economies, vol. 9, no. 1, pp. 75-99, 2015.

S. Shrestha \& N. K. Joshi, Remittances and Financial Inclusion: Evidence from Nepal, New York University, Shanghai, China, 2018.

M. Spence, "Job market signaling," The Quarterly Journal of Economics, vol. 90, no. 4, pp. 629-649, 1973.

O. Stark, "The Economics of International Labour Migration," Population Studies, vol. 44, no. 1, pp. 181-182.

J. E. Stiglitz, and A. Weiss,"Credit rationing in markets with imperfect information," The American economic review, vol.71 no. 3, pp. 393-410, 1981.

H. Toxopeus, and R. Lensink, "Remittances and financial inclusion in development," Development Finance in the Global Economy, pp. 236-263, 2008.

E. Uchenna, S. E. Osabuohien, and S. Oluwatobi, "One dollar, one bank account: remittance and bank breadth in Nigeria," Journal of International Migration and Integration, vol. 16, no. 3, pp. 761-781, 2015.

H. A. White, "Heteroskedasticity Consistent Covariance Matrix Estimator and a Direct Test for Heteroscedasticity," Econometrica, vol. 48, no. 4 , pp. $817-838,1980$.

World Bank Group, Migration and remittances; Developments Brief and, World Bank Report. Washington, D.C., 2019.

World Bank Group \& KNOMAD Migration and remittances; Recent Developments and Outlook, World Bank Report. Washington, D.C., 2018

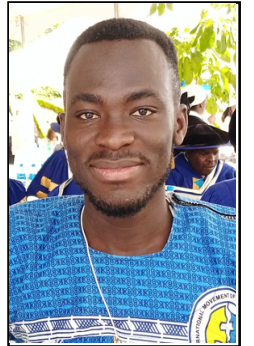

Emmanuel Kwesi Arthur, currently pursues a Master of Science in Finance from Kenyatta University, Kenya and double up as an ACCA student. He holds a Bachelors of Education in Accounting and Business Management from University of Cape Coast, Ghana. His research interests cuts across; Diaspora Remittances, Financial Inclusion, Finance, Financial Accounting, Banking and Investment Analysis.

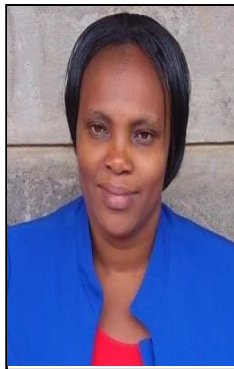

Dr. Salome Mwongeli Musau, CPA (K), holds a PhD degree in Finance from Kenyatta University, Kenya. She is currently a lecturer at Department of Accounting and Finance, School of Business, Kenyatta University and also a member of Certified Public Accountants, Kenya. She has published several papers in reputable journals and also attended both local and international conferences. Further, she has successfully supervised several students at undergraduate and postgraduate levels. His research interest are Financial Inclusion, Entrepreneurial Finance, Public Finance and Financial Management.

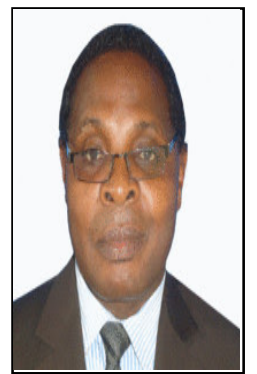

Dr. Festus Mithi Wanjohi, CPA (K), holds a PhD degree in Finance and Strategic Management from Jomo Kenyatta University, Kenya. He is currently a lecturer at Department of Accounting and Finance, School of Business, Kenyatta University and also a member of Certified Public Accountants, Kenya. He has published several papers in reputable journals and also attended both local and international conferences. Further, he has successfully supervised several students at undergraduate and postgraduate levels. His research interest are Management Consultancy, Financial assurance and Forensic audit, and Risk management assurance services. 